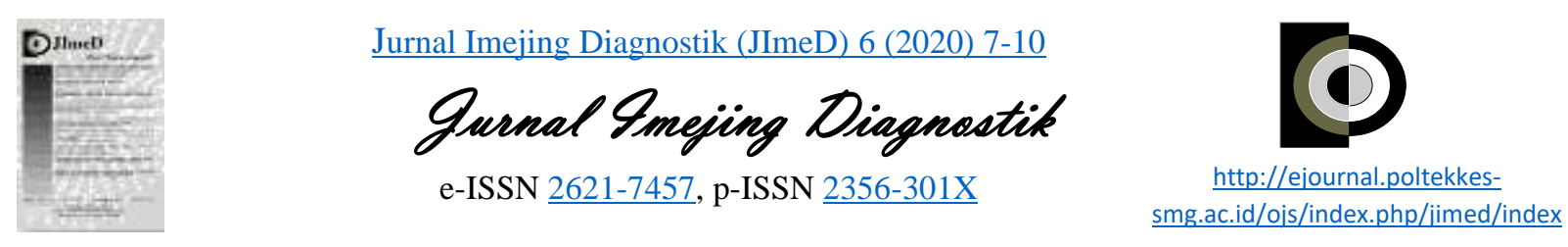

\title{
Pembuatan Phantom Radiologi Berbahan Dasar Kayu Lokal sebagai Pengganti Tulang Manusia
}

\author{
Widya Mufida ${ }^{1}$ Asih Puji Utami ${ }^{2}$ Sofie Nornalita Dewi ${ }^{3}$ \\ 1,2,3 Aisyiyah University of Yogyakarta, Indonesia \\ Corresponding author: Widya Mufida \\ Email: widyamufida@unisayogya.ac.id
}

Received: November $15^{\text {th }}, 2019$; Revised: January $31^{\text {th }}, 2020$; Accepted: January $31^{\text {th }}, 2020$

\begin{abstract}
Background: Phantom radiology is used as a medium of learning as a substitute for human bones. In its use, this phantom radiology has economic value high enough to be an obstacle to the learning process. Therefore, it is necessary to make a phantom with basic materials that are easily accessible and have the same density value as human bones.

Methods: the method used throughout this study is through an experimental approach. The research stage involves testing the density of wood by comparing the density value of the sample used, determining the composition of the mixture between wood, contrast media and adhesives that produces phantom with the density that most closely resembles bone phantom.

Results: From the results of the research, the density value of the anthropomorphic phantom humerus was 9034, and the information obtained for the density value of the four wood phantoms with basal values. Based on the results of the calculation of the density value obtained the highest value on phantom 1 with a density value of 12775 , phantom with the lowest density value of 7682 , namely the second phantom, the value of wood phantom density is quite close to the density value of anthropomorphic humerus phantom, namely phantom 3 with a density of 8986 and Phantom 4 density which is slightly above the wood Phantom 2 density value is 7773 .

Conclusions: In this study to produce wood phantom with a density that resembles bone phantom is carried out with local wood base material mixed with $\mathrm{BaSO} 4$ contrast media so that the average density value is 8986 close to the density value in the anthropomorphic bone phantom humerus.

Keyword: phantom; radiology; wood; contrast media
\end{abstract}

\section{Pendahuluan}

Phantom merupakan alat peraga untuk pengetahuan tentang anatomi tubuh yang digunakan oleh institusi pendidikan dalam menangani pasien dan alat uji peralatan. Fungsi phantom sebagai alat peraga yaitu merupakan media pembelajaran yang berisi ciri-ciri dari konsep dan kompetensi yang dipelajari. Sedangkan fungsi phantom sebagai alat uji peralatan khusunya radiologi sebagai alat bantu dalam mengukur kelayakan alat radiologi tertentu. Pemanfaatan phantom lainnya pada penelitian sebelumnya yaitu sebagai media dalam pengukuran dosis radiasi khususnya Brakiterapi. Rancangan phantom dibuat dari tujuh lapis plat flexiglass tebal $10 \mathrm{~mm}$ dengan ukuran lebar $105 \mathrm{~mm}$ dan panjang $280 \mathrm{~mm}$. Phantom dapat digunakan umuk membuat isodosis sistem (Harkanto, Puspito,\& Triyanto, 2009) ${ }^{l}$.

Berdasarkan manfaat penggunaan phantom maka beberapa penelitian terkait pembuatan phantom telah banyak dilakukan salah satunya yaitu pembuatan phantom pelvis wanita india yang bertujuan untuk merancang dan mengembangkan mirip dengan organ aslinya khusunya meniru dimensi panggul wanita India dengan menggunakan pengganti jaringan yang tersedia secara lokal dan biaya efektif yang memiliki sifat yang sesuai dengan kebutuhan(Shrotriya, Yadav, Srivastava, \& Verma, 2018). 
Pembuatan phantom juga dilakukan untuk memberikan gambaran pada objek organ genu dengan menggunakan bahan dasar gips dapat memberikan gambaran radiograf yang mirip dengan tulang genu manusia (Sofyan,Hidayati, \& Mayani, 2017) ${ }^{4}$. Phantom juga mempunyai struktur tulang yang tertutup dengan gel lunak dalam kulit yang didukung dengan material keras. Phantom radiologi yang ada di pasaran harganya cukup mahal dan harus diimpor dari negara-negara maju yang memproduksi phantom radiologi. Hal inilah yang menjadi kendala bagi institusi pendidikan khususnya radiologi untuk menyediakan phantom radiologi dalam proses pembelajaran. Untuk itu perlu dilakukan penelitian pembuatan phantom menggunakan bahan lain yang lebih ekonomis namun dapat memberikan hasil pencitraan yang sama setelah diekspose dengan sinar $\mathrm{x}$

\section{Metode}

Secara umum metode yang digunakan dalam penelitian ini yaitu melalui pendekatan eksperimen. Penelitian dilakukan dilakukan di Laboratorium Radiologi Universitas 'Aisyiyah Yogyakarta, Tahap penelitian meliputi uji kerapatan kayu dengan perbandingan nilai densitas dengan sampel yang digunakan, menentukan komposisi dari campuran antara kayu, media kontras dan bahan perekat yang menghasilkan phantom dengan densitas yang paling menyerupai phantom tulang, pengolahan kayu lokal menjadi phantom tulang dengan diameter seperti tulang humerus, pengolahan data meliputi pengambilan gambar phantom kayu, pengukuran densitas pada phantom kayu. Penetapan tegangan $\mathrm{kV}$ dan arus (mAs) sesuai dengan standar yang telah ditentukan pada organ manusia. Uji kualitas citra dilakukan dengan mengukur nilai densitas antara phantom anthropomorphic humerus dan phantom kayu, sehingga dapat dihasilkan phantom kayu dengan nilai densitas yang mendekati nilai densitas phantom antrophomorphic humerus.

\section{Hasil dan Pembahasan}

Untuk mendapatkan komposisi yang tepat sehingga phantom memiliki densitas yang sama dengan phantom antrophomorphic humerus, maka dilakukan beberapa kali pengujian. Adapun hasilnya sebagai berikut :

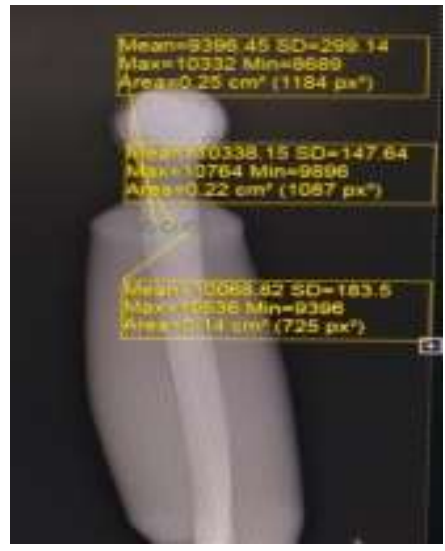

Gambar 1 Nilai densitas phantom antrophomorphic humerus

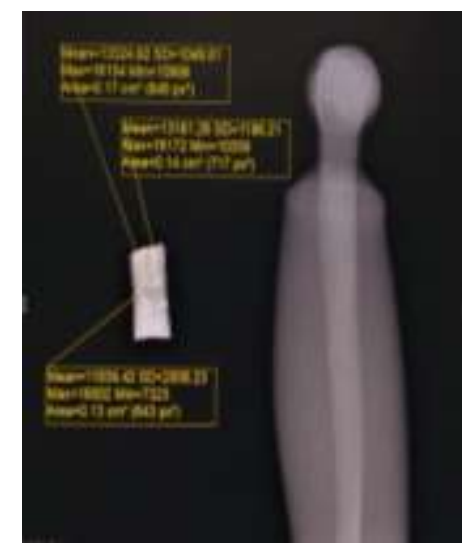

Gambar 2 Nilai densitas pada Phantom 1 dan phantom antrophomorphic humerus

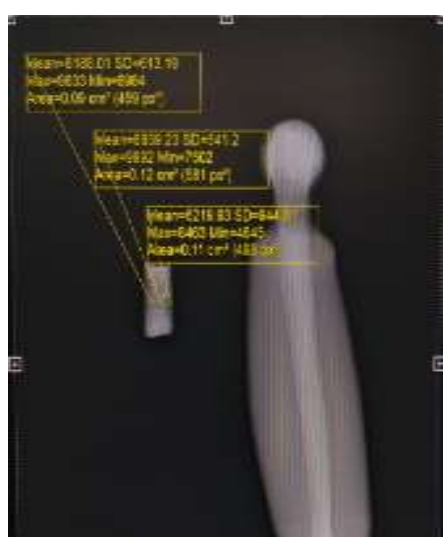

Gambar 3 Nilai densitas pada Phantom 2 dan phantom antrophomorphic humerus 


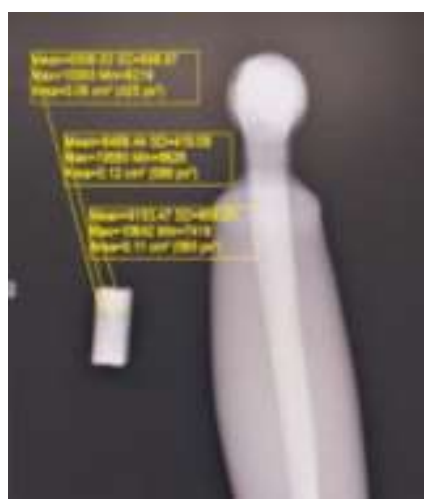

Gambar 4 Nilai densitas pada Phantom 3 dan phantom antrophomorphic humerus

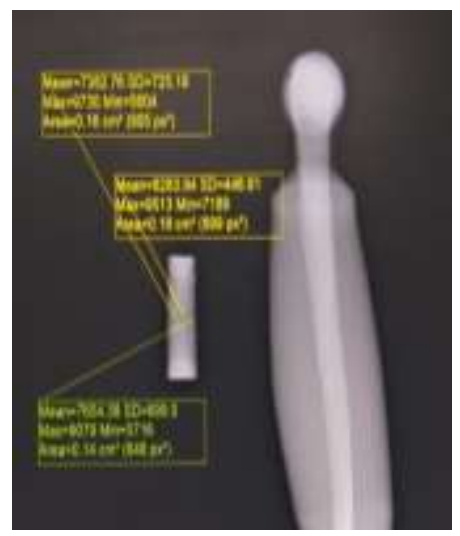

Gambar 5 Nilai densitas pada Phantom 4 dan phantom antrophomorphic humerus

Tabel 1 Nilai densitas phantom kayu

\begin{tabular}{cccccc}
\hline No & Phantom & \multicolumn{3}{c}{ Nilai Densitas } & $\begin{array}{c}\text { Rata-rata } \\
\text { Nilai } \\
\text { Densitas }\end{array}$ \\
\hline $\mathbf{1}$ & $\begin{array}{c}\text { Phantom } \\
\text { Humerus }\end{array}$ & 8496 & 9438 & 9168 & 9034 \\
\hline $\mathbf{2}$ & Phantom 1 & 13324 & 13161 & $\begin{array}{c}1183 \\
9\end{array}$ & 12775 \\
\hline $\mathbf{3}$ & Phantom 2 & 8188 & 8639 & 6219 & 7682 \\
\hline $\mathbf{4}$ & Phantom 3 & 8306 & 9499 & 9153 & 8986 \\
\hline $\mathbf{5}$ & Phantom 4 & 7382 & 8283 & 7654 & 7773 \\
\hline
\end{tabular}

Dari hasil penelitian didapatkan nilai densitas phantom antrophomorphic humerus adalah 9034, dan diperoleh informasi nilai densitas keempat phantom kayu dengan nilai yang bergam. Berdasarkan hasil perhitungan nilai densitas tersebut didapatkan nilai tertinggi pada phantom ke 1 dengan nilai densitas 12775 , phantom dengan nilai densitas terendah sebesar 7682 yaitu phantom Copyright @2020 Authors, JURNAL IMAGING DIAGNOSTTIK, e-ISSN 2621-7457, p-ISSN 2356-301X ke 2, nilai densitas phantom kayu yang cukup mendekati nilai densitas phantom antrophomorphic humerus yaitu phantom 3 dengan densitas 8986 dan nilai densitas phantom 4 yang sedikit diatas nilai densitas phantom kayu 2 yaitu 7773 .

Berdasarkan manfaat penggunaan phantom maka beberapa penelitian terkait pembuatan phantom telah banyak dilakukan salah satunya yaitu pembuatan phantom pelvis wanita india yang bertujuan untuk merancang dan mengembangkan mirip dengan organ aslinya khusunya meniru dimensi panggul wanita India dengan menggunakan pengganti jaringan yang tersedia secara lokal dan biaya efektif yang memiliki sifat yang sesuai dengan kebutuhan. Bahan yang digunakan yaitu lilin parafin, bubuk lidah buaya, boraks murni, dan natrium benzoat, digunakan untuk komposis kerapatan yang tepat dan nomor menggunakan atom yang efektif. Permukaan luar berbentuk tiga dimensi yang berongga dan cetakan organ internal menggunakan gypsona bandage. Hasil penelitian tersebut menyatakan bahwa phantom panggul wanita sebanding dengan dimensi ratarata pelvis wanita India. Pengujian phantom dilakukan secara radiologi yang sama dengan panggul wanita manusia India yaitu berdasarkan CT Number pada rahim, kandung kemih, rektum, otot, lemak, tulang, dan gigi berlubang dan berdasarkan kerapatan elektron relatif dari otot, lemak dan tulang (Shrotriya, Yadav, Srivastava, \& Verma, 2018).

Bahan phantom utama yang akan digunakan dalam penelitian ini yaitu diambil dari bahan kayu lokal. Dimana pemanfaatan kayu lokal sebelumnya telah digunakan sebagai bahan pembuatan stepwedge. Hal tersebut ditunjukkan pada penelitian tentang stepwedge berbahan kayu lokal sebagai phantom yang dipaparkan oleh pesawat sinar-x. Tiga jenis kayu digunakan yakni Seumantok, Meranti Merah dan Medang Kuning. (Nurjannah, Safitri, \& Yusibani, 2018)

Kayu merupakan objek dengan tingkat kerapatan yang jauh lebih rendah dibandingkan dengan tulang, selain itu struktur kayu yang berserat menyebabkan densitas kayu tidak homogeny. Oleh karena untuk menghasilkan nilai densitas yang mendekati tulang diperlukan bahan 
dengan kerapatan yang tinggi untuk dicampurkan dengan kayu. Pembuatan phantom juga dilakukan untuk memberikan gambaran pada objek organ genu dengan menggunakan bahan dasar gips dapat memberikan gambaran radiograf yang mirip dengan tulang genu manusia. Namun gambaran radiograf soft tissue dari bahan campuran resin dan katalis belum memberikan gambaran yang mirip dengan gambaran radiograf soft tissue manusia (Sofyan, Hidayati, \& Mayani, 2017).

Salah satu bahan dengan nilai densitas yang tinggi yaitu media kontras positif yang digunakan pada pemeriksaan radiologi. Media kontras menurut Bontrager (2010) adalah bahan yang dapat digunakan untuk menampakkan struktur gambar suatu organ tubuh (baik anatomi maupun fisiologi) dalam pemeriksaan radiologi, dimana dengan foto polos biasa organ tersebut kurang dapat dibedakan dengan jaringan sekitarnya karena mempunyai densitas yang relatif sama. Sedangkan definisi media kontras menurut Frank (2012) adalah senyawa-senyawa yang digunakan untuk meningkatkan visualisasi (visibility) strukturstruktur internal pada sebuah pencitraan diagnostik medik Media kontras positif yang sering digunakan dan dijumpai antara lain yaitu media kontras barium dan iodine pada sebuah pencitraan diagnostik medik yang dipakai pada pencitraan dengan sinar $\mathrm{X}$ untuk meningkatkan daya atenuasi sinar X (bahan kontras positif).

Barium sulfat (BaSO4) berbentuk bubuk putih yang tidak larut berbentuk suspensi atau serbuk. Barium sulfat adalah agen kontras yang digunakan dalam bentuk suspensi untuk evaluasi traktus gastrointestinal. Barium sulfat tidak cocok digunakan dalam rongga tubuh atau sendi karena dapat memicu terjadinya reaksi granulomatous (Kealy et al. 2011, sedangkan media kontras iodine merupakan media kontras berbentuk cair yang bila mengeras dapat membentuk Kristal. Kedua media kontras tersebut memiliki kesamaan yaitu nilai atomnya tinggi dan molekulnya yang kecil, sehingga mudah dicampurkan dengan serbuk kayu dan bahan perekat untuk kemudian dicetak menyerupai bentuk tulang. Adapun menurut gambar 2 rasio yang paling optimal dalam menghasilkan phantom kayu dengan densitas yang menyerupai phantom tulang didapat pada phantom 3 dengan densitas rata-rata yang didapat 8986 mendekati nilai densitas pada phantom antrohomorphic tulang humerus.

Terima kasih diucapkan kepada Ditjen Penguatan Riset dan Pengembangan sebagai pemberi dana hibah penelitian tahun anggaran 2019.

\section{Simpulan}

Pada penelitian ini untuk menghasilkan phantom kayu dengan densitas yang menyerupai phantom tulang, bahan dasar yang digunakan adalah kayu lokal dicampur media kontras BaSO4, sehingga didapat nilai densitas rata-rata adalah 8986 mendekati nilai densitas pada phantom antrohomorphic tulang humerus. Dengan adanya bahan alternatif ini dapat digunakan sebagai alternatif yang di gunakan untuk dilakukan pengganti praktek dari bahan kayu yang di campur dengan kontras $\mathrm{BaSO} 4$ tersebut dan juga dapat di tentukan ukuran dari pembuatan tersebut.

\section{Daftar Pustaka}

Bontrager, Kenneth.L,2010. Text Book of Radiographic Positioning And R e l a t e d A n a t o $m y$ - Eigth edition.St.Louis;Mousby.Inc

Frank, Aguene, D, 2012 Frank Merrills Atlas of Radiographic Position and Radiographic Prosedure Volume Two New York Year Book Inc

Kealy JK, McAllister H, Graham JP. 2011. Diagnostic Radiology and Ultrasonography of Dog and Cat. 5th ed. Missouri: Elsevier Scienc.

Nurjannah, Safitri, R., \& Yusibani, E. (2018). Studi tentang Stepwedge Berbahan Kayu lokal untuk Jaminan keamanan dalam Radiologi Diagnostik. Journal of Aceh Physics Society (JAcPS) Vol. 7 No.1, 43-49

Shrotriya, D., Yadav, R. S., Srivastava, R. N., \& Verma, T. R. (2018). Design and Development of an Indigenous In-house Tissue-Equivalent Female Pelvic Phantom for Radiological Dosimetric Applications. Irianian Journal of Medical Physics (IJMP) Volume 15 Issue 3, 200-205.

Sofyan, M., Hidayati, A. O., \& Mayani, A. N. (2017). Pembuatan Phantom dari Gips sebagai Pengganti Tulang Manusia dan Bahan Akrilik sebagai Pengganti Soft Tissue. Journal of Health Vol.4 No. $2,107-11$ 